\title{
IDEOLOGI TOKOH TINA DALAM NOVEL KLETING KUNING KARYA MARIA A. SARDJONO
}

\author{
Aryani \\ Program Studi Sastra Indonesia, Universitas Pamulang \\ dosen01161@unpam.ac.id
}

\begin{abstract}
Abstrak
Tulisan ini membahas ideologi tokoh perempuan Tina dalam novel Kleting Kuning karya Maria A. Sardjono yang berkisah tentang seorang gadis cantik yang berpenampilan dan berkelakuan seperti lakilaki. Tulisan ini bertujuan untuk mendeskripsikan pandangan feminisme terhadap ideologi tokoh Tina dalam novel Kleting Kuning. Analisis data dilakukan dengan menggunakan metode deskriptif dan pendekatan feminism dengan menggunakan pendekatan analisis teks. Teknik yang digunakan adalah teknik analisis gender. Data dari penelitian ini berupa data verbal. Paparan bahasa dari pernyataan tokoh yang berupa dialog, monolog, dan narasi yang ada dalam novel Klenting Kuning karya Maria A. Sardjono. Instrumen yang digunakan adalah peneliti sendiri, karena data yang diperoleh dari dokumen, berupa data verbal atau tulisan. Dalam penelitian ini, kedudukan peneliti adalah sebagai perencana, pelaksana, pengumpul data, penganalisis, penafsir data, dan pelaporan hasil penelitiannya. Dalam hal ini peneliti bertindak sebagai pembaca yang aktif, terus menerus membaca, mengamati, dan mengidentifikasi satuan tutur yang sesuai dengan tujuan penelitian, kemudian menafsirkan dan melaporkan hasilnya untuk membantu peneliti dalam mengumpulkan dan menganalisis data penelitian digunakan instrumen pembantu berupa paduan kodifikasi data. Deskripsi pembahasan difokuskan pada karakter tokoh Tina dalam paham feminisme. Hasil pembahasan menunjukkan bahwa ideologi tokoh Tina menggabungkan karakter maskulin dan feminim. Kekuatan yang menjadi ciri maskulin dalam pandangan tradisional berpadu dengan kelembutan ciri feminim. Kombinasi ini membantu Tina menjalani kehidupan dengan baik dalam lingkungannya.
\end{abstract}

Kata Kunci: Feminisme, novel, dan ideologi perempuan

\begin{abstract}
This paper discusses the ideology of female characters in the novel Kleting Kuning Tina by Maria a. Sardjono telling about a beautiful girl who looks and behave like men. This paper aims to describe the views of feminism against ideological character Tina in the novel Kleting Kuning. Data analysis was done using descriptive method and approach to feminism by using text analysis approach. The technique used was gender analysis techniques. Data from this research in the form of verbal data. Exposure to the language of the state figures in the form of dialogues, monologues, and a narrative that exists in the novel Klenting Kuning by Maria a. Sardjono. The instruments used are the researchers themselves because the data is obtained from the document, in the form of verbal or text data. In this study, the researcher's position is as planners, implementers, collecting data, Analyzer, data interpreter, and reporting the results of his research. In this case the researchers. In this case, the researchers acted as readers are active, constantly reading, observing, and identifying the units said that in accordance with the research objectives, and then interpret and report the results to help researchers in collecting and analyzing research data used instrument helper form alloys a codification of the data. Description of the discussion focused on the character of the character of Tina to understand feminism. The results of the discussion indicate that ideology figures Tina combine masculine and feminine character. The power that characterizes the traditional view of masculine in combination with the softness of feminine traits. This combination helped Tina living well in their environment.
\end{abstract}

Key Words: Feminism, novel, and the ideology of women 


\section{PENDAHULUAN}

Literasi merupakan kemampuan seseorang untuk bisa membaca dan menulis guna menunjang dan meningkatkan kualitas hidupnya. Menumbuhkan gerakan literasi tidaklah semudah membalikkan tangan. Hal ini sangat membutuhkan kreativitas, energi, dan dukungan dari berbagai kalangan. Partisipasi masyarakat dalam membangun literasi mulai menggeliat akhir-akhir ini di Indonesia dengan banyak bermunculannya komunitas literasi, baik dil ingkungan sosial masyarakat, sekolah, kampus, dan lainnya bahkan mulai banyaknya dukungan dari birokrasi pemerintahan bagi gerakan literasi.

Salah satu karya sastra yang dapat dijadikan acuan literasi adalah karya sastra dari penulis perempuan. Para penulis berupaya menciptakan lakon perempuan yang sesuai dengan keinginan mereka, sosok yang berbeda dengan yang biasa ditampilkan penulis pria. Pengarang perempuan berupaya mendefinisikan dunianya. Bahasa perempuan yang tertuang dalam karya fiksi dan non-fiksi dapat disikapi sebagai wacana, yakni cara mengatakan, menulis atau membahasakan peristiwa, pengalaman, pandangan, dan kenyataan hidup tertentu. Bahasa perempuan selalu merepresentasikan model pandangan hidup tertentu, yakni gambaran sebuah konstruksi dunia yang bulat dan utuh tentang ide hidup dan kehidupan yang sudah ditafsirkan dan diolah perempuan. Sekarang secara luas diterima bahwa perempuan dan laki-laki berbicara secara berbeda. Perempuan lebih sering dan cenderung menggunakan gaya tutur kooperatif, sebaliknya laki-laki lebih cenderung menggunakan gaya kompetitif (Santoso, 2009:1-2).
Dewasa ini, semakin banyak fenomena yang terjadi dalam masyarakat. Sastrawan yang menangkap hal tersebut, menuangkannya dalam sebuah karya dengan disertai hasil pola pikir dan daya kretivitas. Ketika menulis, semua pengarang memiliki publik yang hadir dalam pikirannya, paling tidak dirinya sendiri (Escarpit, 2008:115). Karyanya tidak hanya diharapkan memberikan kesenangan bagi pembacanya, tetapi juga memberikan efek pengajaran atau manfaat. Banyak karya sastra yang memberikan pelajaran, tetapi tidak disampaikan dalam bahasa yang indah dan menyenangkan sehingga efek entertain-nya sebagai karya sastra tidak terpenuhi. Ada pula karya sastra yang menggunakan rangkaian kata yang cantik berbunga-bunga, tetapi tidak membawa pesan apa pun yang bisa disebut sebagai pelajaran atau manfaat. Mengutip apa yang dikemukakan oleh seorang pemikir Romawi, Horatius, beliau mengemukakan istilah dulce et utile yang artinya, sastra mempunyai fungsi ganda, yakni menghibur sekaligus bermanfaat bagi pembacanya (Budianta, 2008:19).

Salah satu penulis perempuan berbakat yang dimiliki negeri ini adalah Maria A. Sardjono dengan karyakaryanya yang selalu fenomenal. Maria A. Sardjono adalah penulis kreatif. Lulusan Sarjana Filsafat Sosial Budaya dan Magister Filsafat Humaniora ini di usia remajanya sudah banyak menghasilkan karya. Di tahun 1974 hasil karyanya mendapat kesempatan untuk dikenal masyarakat. Hingga kini sudah lebih dari 100 judul buku yang dihasilkannya, sebagian di antaranya dipublikasikan sebagai cerita bersambung terlebih dahulu. Tidak hanya buku, dia pun banyak menulis cerpen, cerita anak, naskah sadiwara radio, buku ilmiah, dan artikel dengan 
berbagai macam topik. Novel Kleting Kuning yang diterbitkan oleh PT Gramedia Pustaka Utama di bulan November tahun 2010 untuk dicetak untuk pertama kalinya merupakan salah satu karya terbesarnya.

Tokoh sentral dalam novel ini memiliki pribadi istimewa. Dia luwes dalam menghadapi berbagai situasi dan permasalahan. Pekerjaan apa pun dia mau melakukannya, baik pekerjaan kasar maupun pekerjaan yang membutuhkan perhatian dalam hal kelembutan dan keindahan.

Perempuan dalam masyarakat memiliki tiga peran utama, meminjam istilah dalam teori triple roleperempuan dari Caroline Moser, yaitu ranah publik, domestik, dan sosial. Oleh karena itu, perspektif perempuan sungguh kompleks. Bersama dengan sosok lakilaki, perempuan mengalami proses yang sama, yaitu sebaik-baiknya menjadi anggota dan sekaligus menciptakan masyarakat, atau kebudayaan yang baru (Murniah, 2010:358). Karena sifat perannya yang domestik tadi, perempuan sebenarnya punya keterkaitan dengan konteks sosial di mana mereka hidup (Fauzia, 2004:121).

Merujuk pada apa yang telah dipaparkan, penulis berusaha mengungkap ideologi yang dimiliki oleh tokoh Tini dalam novel Kleting Kuning karya Maria A. Sardjono. Hal tersebut menarik, mengingat tokoh perempuan tersebut diciptakan oleh seorang penulis perempuan. Meski dunia fiksi dan realita tidaklah dapat disandingkan secara sejajar.

Berikut merupakan beberapa kajian pustaka terkait dengan penelitian ini: pendekatan feminis yaitu kritik sastra yang menyoroti permasalahan perempuan sebagai tema sentral sehingga perempuan sebagai objek analisis. Budianta (dalam Sulistiati, 2010:4) mengatakan bahwa pendekatan feminis pada intinya adalah sebuah kritik ideologis terhadap cara pandang yang mengabaikan permasalahan ketimpangan dan ketidakadilan dalam pemberian peran dan identitas sosial berdasarkan jenis kelamin. Hal yang tidak bisa dilepaskan dari kritik sastra feminis adalah jiwa analisisnya yakni analisis gender. Gender merupakan konstruksi secara sosial dan kultural yang pada dasarnya merupakan interpretasi kultural atas perbedaan jenis kelamin.

Ideologi dalam kamus Besar Bahasa Indonesia (KBBI, 2008:517) berarti cara berpikir seseorang atau suatu golongan, atau kumpulan konsep bersistem yang dijadikan asas pendapat (kejadian) yang memberikan arah dan tujuan untuk kelangsungan hidup. Bila diartikan ideologi sebagai himpunan nilai, ide, norma, kepercayaan, dan keyakinan yang dimiliki seseorang atau sekelompok orang yang menjadi dasar dalam menentukan sikap terhadap kejadian dan problem yang dihadapinya dan yang menentukan tingkah laku.

Novel merupakan salah satu jenis fiksi. Novel dan cerita pendek merupakan dua bentuk karya sastra yang sekaligus disebut fiksi. Bahkan dalam perkembangannya novel dianggap bersinonim dengan fiksi. Dengan demikian, pengertian fiksi juga berlaku untuk novel (Nurgiantoro, 1995:9).

Dapat disimpulkan novel atau cerita rekaan adalah satu genre sastra yang dibangun oleh unsur-unsur pembangun sebagai sebuah struktur yang secara fungsional memiliki keterjalinan ceritanya; untuk membangun totalitas makna dengan media bahasa sebagai penyampai gagasan pengarang tentang hidup dan seluk-beluk kehiduan manusia. Dengan kata lain novel adalah sebuah karya 
prosa fiksi yang tertulis naratif; biasanya dalam bentuk cerita.

Dalam tulisan ini akan dibahas mengenai ideologi perempuan dari sudut padang tokoh perempuan yang terdapat dalam novel Kleting Kuning karya Maria A. Sardjono. Pelaku atau tokoh novel yang menjadi objek peneltian adalah tokoh Tini yang terdapat dalam novel Kleting Kuning karya Maria A. Sardjono. Teknik analisis yang dipakai dalam mengidentifikasi tokoh perempuan dalam novel ini, kedudukan dan pemikirannya, serta cara penulis perempuan dalam karyanya. Sumber data kajian ini adalah novel Kleting Kuning karya Maria A. Sardjono yang diterbitkan PT Gramedia Pustaka Utama tahun 2010. Melalui pendekatan feminis, penulis berusaha memaparkan ideologi tokoh Tini pada novel Kleting Kuning karya Maria A. Sardjono.

\section{METODE PENELITIAN}

Penelitian ini adalah penelitian kualitatif dengan pendekatan deskriptif. Data penelitian desktiptif disajikan dalam bentuk kata-kata atau gambar, bukan angka, meliputi transkip wawancara, catatan lapangan, foto, rekaman video, dokumen pribadi, memo dan catatan-catatan resmi lainnya (Handayani dan Sugiarti, 2008: 53). Analisis data dilakukan dengan menggunakan pendekatan analisis teks. Teknik analisis yang dipakai dengan mengidentifikasi ideologi tokoh Tini, kedudukan dan pemikirannya, serta cara pengarang menggambarkan ideologi tokoh Tini dalam karyanya. Data dari penelitian ini berupa data verbal. Paparan bahasa dari pernyataan tokoh yang berupa dialog, monolog, dan narasi yang ada dalam novel Klenting Kuning karya Maria A. Sardjono. Instrumen yang digunakan adalah peneliti sendiri, karena data yang diperoleh dari dokumen, berupa data verbal atau tulisan. Dalam penelitian ini, kedudukan peneliti adalah sebagai perencana, pelaksana, pengumpul data, penganalisis, penafsir data, dan pelaporan hasil penelitiannya. Dalam hal ini peneliti bertindak sebagai pembaca yang aktif, terus menerus membaca, mengamati, dan mengidentifikasi satuan tutur yang sesuai dengan tujuan penelitian, kemudian menafsirkan dan melaporkan hasilnya untuk membantu peneliti dalam mengumpulkan dan menganalisis data penelitian digunakan instrumen pembantu berupa paduan kodifikasi data. Deskripsi pembahasan difokuskan pada karakter tokoh Tina dalam paham feminisme. Lebih lanjut lagi, Ratna (2010: 337) menjelaskan metode deskriptif sebagai metode yang lebih banyak berkaitan dengan kata-kata, data primer berupa realitas budaya dapat dirupakan dalam bentuk kalimat untuk dianalisis.

Pengumpulan data dilakukan dengan menggunakan metode pustaka, dengan mengambil sumber data penelitian novel berjudul Kleting Kuning karya Maria A. Sardjono, sehingga data sudah berupa rangkaian kata-kata/kalimat. Data berupa kalimatkalimat di dalam novel yang memuat representasi ideologi yang muncul dalam tokoh Tina. Data yang ada dianalisis menggunakan pendekatan kualitatif dengan teknik induktif, yakni mengkaji hal khusus, sebagaimana pendapat Handayani dan Sugiarti (2008: 54) yang menyebutkan bahwa analisis dalam penelitian kualitatif cenderung dilakukan secara induktif, di mana peneliti membuat abstraksi sebagai pencerminan keunikan dari fenomena yang akan diteliti. Dalam tulisan ini, fenomena yang akan diteliti ialah representasi konsep ideologi dalam 
tokoh Tina dalam novel Kleting Kuning karya Maria A. Sardjono, untuk mengungkapkan hal yang umum, yaitu pemahaman makna ideologi tokoh sentral dalam novel Kleting Kuning dalam pemahaman kaum feminis. Pengkajian data dilakukan dengan mengacu pada pandangan feminisme.

\section{HASIL DAN PEMBAHASAN}

\section{Tentang Pengarang}

Maria A. Sardjono adalah penulis kreatif. Lulusan Sarjana Filsafat Sosial Budaya dan Magister Filsafat Humaniora ini di usia remajanya sudah banyak menghasilkan karya. Maria mulai menulis sejak masih usia remaja, tetapi di tahun 1974 hasil karyanya baru dipulikasikan dan mendapat kesempatan untuk dikenal masyarakat. Hingga kini sudah lebih dari 100 judul buku yang dihasilkannya, sebagian di antaranya dipublikasikan sebagai cerita bersambung terlebih dahulu. Tidak hanya buku dan cerita bersambung, dia pun banyak menulis cerpen kurang dari 150 judul cerpen, belasan cerita anak, naskah sandiwara radio, satu buku ilmiah, dan puluhan judul artikel dengan berbagai macam topik. Novel Kleting Kuning yang diterbitkan oleh PT Gramedia Pustaka Utama di bulan November tahun 2010 dicetak untuk pertama kalinya merupakan salah satu karya terbesarnya. Maria A. Sardjono lulus sebagai Sarjana Filsafat Sosial Budaya dan Magister Filsafat Humaniora (bukabuku.com, 2018).

\section{Sinopsis Novel Kleting Kuning}

Kleting Kuning berkisah tentang kehidupan seorang gadis bernama Tri Agustina Kusumawardani yang biasa dipangil "Tina". Tina memiliki karakter khusus, tidak seperti gadis-gadis pada umumnya. Di rumah, ia dijuluki Kleting Kuning, sebuah nama yang melekat pada tokoh dongeng Jawa Tengah, yakni seorang gadis cantik yang tinggal bersama ibu dan beberapa saudara tirinya. Kleting Kuning dalam dongeng didomestikkan oleh keluargnya, sedangkan Kleting Kuning Tina tidak. Tina memang suka mengerjakan pekerjaan apa saja yang ada di rumahnya, baik pekerjaan dalam rumah maupun pekerjaan di luar rumah semisal memperbaiki mesin mobil. Namun, hal itu bukan hasil pemaksaan siapa pun. Ia melakukannya dengan senang hati. Dalam perekonomian keluarga, Tina menjadi pengganti kedua orang tuanya saat mereka berhalangan menjalankan usaha keluarga. Pendek kata, Tina adalah seorang gadis serba bisa.

Sehari-harinya Tina berpenampilan seperti laki-laki, dengan pakaian kaos dan celana jeans, rambut pun dipotong pendek. Sekilas ia terlihat seperti seorang pemuda yang manis. Tina banyak mengatakan hal terkait dengan keadaan dirinya yang terkesan tidak peduli dengan hal keperempuanannya, bahkan lebih terlihat seperti laki-laki. Tina memiliki alasan logis untuk itu semua. Dalam perjalanan kehidupannya, Tina berkenalan dengan seorang pemuda (Irawan) yang cenderung tidak pedulian, bahkan pada awal perjumpaan mereka terkesan sangat menyebalkan. Tampaknya, karakter Tina yang biasanya mengabaikan aspek feminitas dalam dirinya, kena batunya dengan karakter Irawan yang biasa juga tidak memedulikan pergaulan dengan lawan jenis. Gayung bersambut, dengan segala kisah romantiknya, mereka pun resmi menjadi sepasang kekasih. Pada akhirnya Tina bertemu seorang pemuda yang cenderung tidak memedulikan pergaulan dengan lawan jenis. 


\section{Wacana Feminisme dalam Novel Kleting Kuning \\ Tokoh perempuan yang} digambarkan pengarang adalah tokoh perempuan yang secara langsung maupun tidak langsung atau sengaja maupun tidak sengaja memasukkan ideologi feminis yang dibawa dalam bahasa wacana. Dapat dilihat pada uraian berikut:

\section{Aktualisasi Diri}

Tokoh sentral dalam novel ini adalah Tina yang memiliki penampilan dan karakter istimewa bagi seorang perempuan. Kelembutan seorang perempuan sejati yang dimilikinya dikalahkan dengan penampilan yang cenderung terlihat seperti lelaki. Hal ini bisa terbaca dalam sebuah kutipan bagaimana Tina berpenampilan.

Dalam berapa hal memang Tina memiliki persamaan dengan Kleting Kuning.Ia juga tercantik di antara saudara-saudaranya yang juga termasuk gadis-gadis cantik itu. Tetapi ia juga yang paling tidak memedulikan kecantikannya. Rambutya yang bagus itu dipotong pedek, potongan lelaki. Penampilan semaunya sendiri. Semasa duduk di SMP dan SMA, memang ia terpaksa memakai rok untuk pergi ke sekolah. Tetapi di perguruan tinggi, hamper-hampir ia tak pernah mengenakan gaun. Selalu memilih celana yang agak longgar. Sepatunya Kets. Sepintas, ia lebih tampak sebagai pemuda tampan yang kurang maskulin daripada seorang gadis jelita. (Sardjono, 2010:7-8).

Tidak hanya dalam penampilan, Tina pun suka mengerjakan pekerjaan yang biasanya diminati laki-laki, misalnya memperbaiki perkakas dapur bahkan genteng rumah yang bocor. Handal dalam mengemudikan truk dan siap menghadapi kerewelan truk ayahnya ketika mogok di jalan. Semuanya menggambarkan bagaimana besarnya minat Tina kepada pekerjaanpekerjaan itu. Berikut kutipan yang dapat dianggap representatif dari hal tersebut.

"Mau kemana kau, Tina?" Tanya ibu ketika gadis itu pergi menjauhinya. "Membatu Pak Somad membetulkan mesin truk!" sahut yang ditanya. "Ya ampun, Tina, itu biar diselesikan oleh Pak Somad sendiri. Soal-soal mesin seperti itu, kau tak usah ikut memegangnya. Lebih baik membantu Bibik, benah dapur sana. Pekerjaannya sedang banyak tuh."

"Tina ingin belajar banyak soal mesin mobil, Bu. Itu juga penting. Kalau suatu, ketika mobil kita mogok di tengah jalan, Tina jadi tahu juga mengatasinya. Pak Somad pernah belajar montir. Jadi Tina ingin belajar darinya." (Sardjono, 2010:45).

Dari kutipan di atas terlihat ideolog aktualisasi diri tokoh Tina, peran perempuan yang tidak melulu berkutat pada ranah domestik. Semua permasalahan pribadi yang melilit tokoh Tina tidak membuatnya berkecil hati atau bahkan menarik diri dari kehidupan sosial. Namun, menjadi pemicu untuk menggali potensi dan mencari jati diri agar hidup memiliki arti.

Dari kutipan lain terungakap isi hati Tina berkenaan dengan ketertarikannya pada hal-hal yang dianggap maskulin. Tina sama sekali tidak merasa ingin menjadi seorang 
laki-laki. Dia lebih memperjuangkan haknya sebagai individu, terlepas dari permasalahan jenis kelaminnya yang perempuan itu. Berikut kutipannya.

"Tina ingin belajar banyak soal mesin mobil, Bu. Itu juga penting. Kalau suatu ketika mobil kita mogok di tengah jalan, Tina jadi tahu juga mengatasinya. Pak Somad pernah belajar montir. Jadi Tina ingin belajar darinya." (Sardjono, 2010:45)

Pada bagian lain, tersirat alasan lain mengapa Tina lebih suka berpenampilan dan bertingkah laku seperti seorang laki-laki.

"Tetapi kau seorang
gadis dewasa, Tin. Kurang
pantas..."
"Apanya yang kurang
pantas?"Tina memotong
perkataan ibunya. "Pantas atau
tidak pantas itu kan hanya
karena kebiasaan saja.Dulu,
orang merasa aneh melihat
penata rambut dan perancang
pakaian berjenis laki-
laki.Apalagi untuk
memotongkan rambut

kepadanya.Risi rasanya kalau rambut dipegang-pegang oleh lelaki.Tetapi sekarang hal itu sudah biasa dan tidak tampak aneh lagi.Nah, kalau kaum pria bisa mengerjakan hal-hal yang memerlukan kelembutan dan cita rasa, kenapa kaum perempuan tidak bisa memegang hal-hal yang dianggap menjijikkan seperti minyak pelumas yang hitam, lengket, kotor, dan bau? Dan mengapa pula kaum perempuan harus merasa aneh kalau meyukai mesin-mesin, sekrup, dongkrak, dan semacam itu?..." (Sardjono, 2010:45).

\section{Pemberontakan}

Peran perempuan yang terkadang tersubordinat dalam beberapa karya fiksi, terlihat pula pada diri tokoh Tina. Tina sangat sadar akan apa yang menjadi permasalahan kaum perempuan dalam budaya patriaki sebagaimana yang dialaminya, dan juga dialami oleh Lusi, salah satu seorang saudara perempuannya. Tina mengerti pandangan masyarakat terhadap seorang perempuan. Perempuan dianggap lemah dan tidak berdaya tanpa bantuan dan perlindungan laki-laki. Bahkan perempuan sendiri, dalam hal ini contohnya ialah Lusi, yang terkadang memosisikan diri dalam situasi tersebut dengan nyamannya. Tina tidak hendak mengingkari kodratnya sebagai perempuan, ia hanya menginginkan kehidupan terbaik dalam pandangan umum budaya patriaki. Ia ingin menampilkan dirinya yang mandiri, yang dalam banyak hal bisa memiliki kemampuan sama dengan kaum lelaki. Sebetulnya ia merasa tidak suka akan keadaan Lusi yang menurutnya masih saja memiliki ketergantungan pada lakilaki. berikutbeberapa kutipannya:

"Tetapi kau seorang gadis dewasa, Tin. Kurang Pantas..." "Apanya yang kurang pantas?" Tina memotong perkataan ibunya. "Pantas atau tidak pantas itu kan hanya karena kebiasaan saja. Dulu, orang merasa aneh melihat penata rambut dan perancang pakaian berjenis laki-laki. Apalagi untuk memotongkan rambut kepadanya. Risi rasaya kalau rambut dipegang-pegang oleh laki-laki. Tetapi sekarang hal itu sudah biasa dan tidak tampak aneh lagi. Nah, kalau kaum pria 
bisa mengerjakan hal-hal yang memerlukan kelembutan dan cita rasa, kenapa kaum perempuan tidak bisa memegang hal-hal yang dianggap menjijikan seperti minyak pelumas yang hitam, lengket, kotor, dan bau Dan mengapa pula kau perempuan harus merasa aneh kalau menyukai, sekrup, dongkrak, dan semacam itu?..." (Sardjono, 2010:45).

"Kau tak mau melepaskan diri dari citra perempuan yang selalu dinilai lemah dan perlu perlindungan sih!" katanya kemudia.

"Belajarlah mandiri, Lusi. Tunjukkan bahwa laki-laki dan perempuan memilki kemampuan yang sama dalam banyak hal. Kecuali yang disebabkan oleh kodrat bioligisnya." (Sardjono, 2010:17).

Dari kutipan tersebut terbaca isi hati Tina berkenaan dengan ketertarikannya pada hal-hal yang dianggap maskulin. Tina sama sekali tidak merasa ingin menjadi seorang laki-laki. Dia lebih memperjaungkan haknya sebagai individu dan tidak ingin dirinya memilki ketergantungan terhadap seorang laki-laki. Ideologi pemberontakan terhadap realitas yang terdapat pada diri Tina ingin memperlihatkan posisi perempuan yang kuat. Luapan pemberontakan dilakukan dengan cara menarik diri dari dunia perempuan yang lemah dan asyik dengan dunianya yang mandiri.

\section{Rela Berkorban}

Fitrah perempuan yang dipaksa bertahan atau nrimo dengan keadaan dan rela berkorban terlihat pada sosok tokoh Tina.Tina orang yang ringan tangan dan berhati tulus. Terutama terhadap keluarganya. Demi mereka, Tina bersedia melakukan apa saja. Termasuk membetulkan kompor, keran bocor, memasang lampu taman yang mati, memanjat pohon, dan lainnya. Terlihat dari beberapa kutipan berikut.

"Kau memang penuh pengertian, Tina!" sahut ibunya lagi. Kini senyum yang tercipta di sudut bibirnya lebih berupa senyum kasih sayang. "Tanpamu, entah apa yang bisa kami lakukan."

"Ah, Ibu.Apa yang kulakukan itu bukan sesuatu yang istimewa, kok. Ibu kan tahu Kleting Kuning ini suka bekerja." (Sardjono, 2010:46).

Gadis itu baru saja pulang kuliah dan baru pula usai makan siang.

"Pak Somad tidak masuk kerja. Maukah siang ini kau mengantar barang ke tempat yang agak jauh?"

"Harus siang ini?"

"Ya, paling tidak menjelang sore ini. Soalnya pestanya besok malam."

"Asal dengan Wardi, Pak Nurdin, dan Johan." (Sardjono,2010:51).

Dari kutipan di atas nampak jelas karakter Tina yang rela mengedepankan kepentingan orang banyak dari semua kepentingan pribadinya. Dalam kesempatan lain pun bisa dibuktikan berdasarkan kutipan berikut.

Satu minggu menjelang ulang tahun Tina yang kedua puluh empat, salah satu adiknya dilamar keluarga kekasihnya. Sebelum harinya, seluruh keluarganya berkumpul untuk membicarakan acara keluarga itu. 
"Aku lebih memikirkan soal pelangkah!" kata ibunya.

Semua yang ada di ruang itu menatap ke arah Tina. Wajah gadis itu tampak tenang dan tanpa menyiratkan suatu perasaan apa pun.

"Soal sepele begitu kok dipikir sih, Bu," sahut gadis itu dengan acuh tak acuh". Sudah kukatakan, aku rela dilangkahi adikku. Berarti aku juga tidak mengharapkan barang atau benda apa pun untuk pelangkah." (Sardjono, 2010:15).

\section{Keteguhan}

Kemandiriannya dalam mengerjakan pekerjaan kasar tidak lantas membuat Tina merasa dirinya super dan dapat menempatkan orang lain pada posisi di bawahnya. Ia memiliki sisi lain dalam pribadinya. Meskipun berpenampilan tomboi atau kelaki-lakian dan berminat pada hal-hal yang dianggap berlabel maskulin, ia tetap menyukai hal lain yang berhubungan dengan keindahan dan kelembutan sebagaimana layaknya seorang perempuan dalam penerimaan budaya secara umum. Ada banyak bagaian dalam novel ini yang mengeksplisitkan minat Tina dalam halhal kewanitaan. Berikut salah satunya.

"Aku menyukai segala hal yang
mengungkit perasaan. Entah itu
rasa nyaman, keindahan, rasa
damai, kelembutan, atau apa
saja yang menyentuh hati,
"sahut Tina kalem sambil
berusaha tidak tersinggung.
(Sudjono, 2010: 95).

Kutipan di atas adalah ucapan Tina ketika ia merangkai bunga-bunga segar untuk menghiasi meja prasmaan pada acara pertunangan Iwan. Tina juga handal dalam hal memasak. Berikut kutipannya.

Saat melihat gadis itu sibuk menyiapkan sarapan buat mereka semua dengan gesit, tangkas dan dengan hasil masakannya yang lezat, Irwan teringat kembali percakapan mereka tersebut. (Sardjono, 2010:165).

Kutipan di atas sekaligus memberikan keterangan lebih banyak tentang bagaimana karakter Tina. Ia seorang yang memiliki prinsip hidup yang kuat. Karakter yang secara umum dipandang sebagai representasi kejiwaan seorang laki-laki. Namun, Tina yang seorang perempuan pun bisa memegang teguh prinsip-prinsip hidupnya untuk selalu mandiri, tidak bergantung pada siapa pun.

Keputusan untuk bertindak dan bersikap bukanlah perkara yang mudah diambil. Dibutuhkan keberanian, keteguhan, ketegasan, apalagi berkaitan dengan rencana masa depan. Perempuan dengan segala beban yang ditanggungnya adalah sosok yang sangat tangguh. Ia pun dapat memancarkan sinar energy positif pada orang-orang yang dicintainya.

Kite Milet, seorang feminis radikal-libertarian mengatakan bahwa androgini hanya menjadi ideal jika kualitas feminis dan maskulin, yang diintregasikan ke dalam manusia androgini adalah masing-masing berharga (Tong, 2010:76). Karakter Tina sesuai dengan apa yang telah diungkapkan Kite Milet tentang kondisi ideal sebuah keadaan yang disebut androgini. Tina tidak memunculkan arogansi yang identik dengan maskulinitas ataupun kepatuhan yang disebut sebagai ciri khas perempuan dalam pandangan budaya patriarki. Pada saat tidak orang lain yang 
diharapkan membantu menyelesaikan permasalahan yang timbul, Tina bisa dengan mudah memberdayakan dirinya. Ia menjadi lebih mudah dalam menjalani kehidupan dalam lingkungannya. Tidak hanya untuk dirinya, bagi keluarganya pun keberadaan Tina sangat menguntungkan. Tampaklah bahwa androgini yang melekat dalam tokoh Tina sesuai dengan apa yang dikatakan ideal oleh Kate Milet, yaitu bahwa androgini yang ideal ialah penggabungan kualitas terbaik maskulin dan feminism sehingga bisa membantu orang itu mendapatkan suatu kehidupan yang lebih baik di dalam komunitasnya.

\section{SIMPULAN}

Dari pembahasan yang sudah dilakukan mengenai ideologi tokoh Tina dalam novel Kleting Kuning dapat ditarik beberapa simpulan. Tokoh Tina memiliki kualitas maskulin dan feminism dalam dirinya. Kedua kualitas tersebut terungkap dalam teks (novel Kleting Kuning) berada dalam nilai yang positif. Kedaan semacam ini disebut sebagai sebuah keadaan ideal sebagaimana pandangan paham feminis Kate Milet. Tina bisa menjalani kehidupannya dengan lebih baik dalam lingkungannya karena mampu mengombinasikan kekuatan, yang secara tradisional dihubungkan dengan laki-laki dan kelembutan yang secara tradisional dihubungkan dengan perempuan.

Perempuan sebagai mitra lakilaki dalan kehidupan mengambil peran yang berarti. Peluang dan bagian ruang kerja yang ada di ranah publik dimanfaatkan dengan baik oleh tokoh Tina ini tanpa meninggalkan perannya di ranah domestik. Pengarang telah berupaya mengangkat sebagian profil perempuan dan ideologinya dalam diri tokoh Tina. Aktualisasi, pemberontakan, rela berkorban, dan keteguhan merupakan empat cara pandang atau ideologi yang terungkap dalam paparan di atas melalui tokoh Tina dalam novel Kleting Kuning.

\section{DAFTAR PUSTAKA}

Budianta, M. dkk. (2008). Membaca Sastra. Magelang: Indonesia Tera.

Depdiknas. (2008). Kamus Besar Bahasa Indonesia. Edisi keempat. Jakarta: PT Gramedia Pustaka Utama.

Escarpit, R. (2008). Sosiologi Sastra. Ida Sundari Husen (penerjemah). Jakarta: Yayasan Obor Indonesia.

Fauzia, A. dkk. (2004). Tentang Perempuan Islam: Wacana dan Gerakan. Jakarta: PT Gramedia Pustaka Utama.

Handayani, T. dan Sugiarti. (2008). Konsep dan Teknik Penelitian Gender. Edisi Revisi. Surya Dharma (editor). Malang: UPT Penerbitan Universitas Muhammadiyah Malang.

Murniah, Y. (2010). Kompleksitas Suara Perempuan Urban dalam Novel. Prosiding Konferensi Internasional Kesusastraan XXI HISKI.

Nurgiantoro, B. (1995). Teori Pengkajian Fiksi. Yogyakarta: Gajah Mada University Press.

Ratna, N. K. (2010). Metodologi Penelitian Kajian Budaya dan Ilmu Sosial Humaniora pada 
Umumnya. Yogyakarta: Pustaka Pelajar.

Santoso, A. (2009). Bahasa Perempuan: Sebuah Potret Ideologi Perjuangan. Jakarta: Bumi Aksara.

Sardjono, M. A. (2010). Kleting Kuning. Jakarta: PT Gramedia Pustaka Utama.
Tong, R. P. (2010). Feminist Thought: Pengantar Paling Komprehensif Kepada Arus Utama Pemikiran Feminis. Terj. Aquarini Priyatna Prabasmoro. Yogyakarta: Jalasutra.

Bukabuku.com. (2018). Daftar Pengarang. Diambil dari http://www.bukabuku.com/auth orscorner/detail/104/maria-asardjono.html. Diakses pada tanggal 17 April 2018. 